\title{
Legal Status of an Appraiser in the Russian Federation under Globalization
}

\author{
Abdreev T.I. \\ Tufetulov A.M.
}

Kazan Federal University, Institute of Management, Economics and Finance, Kazan, 420008, Russia

\section{Doi:10.5901/mjss.2014.v5n24p188}

\section{Abstract}

This paper studies the functioning of the professional appraiser institute in the Russian Federation, the problems of legal regulation of appraisal activities in the Russian Federation, explores the experience of regulating appraisal activities in the United States. In view of the foregoing, and the gaps in the regulation of this sector of the economy in our country, the experience of developed countries in this area seems interesting, particularly in the United States. At the moment in every European country, which is a member of the IVSC or TEGOVA, there are national regulatory regimes for valuation. In this case, the regulation of valuation in the United States is different, for example, from the regulation of valuation in the UK or Germany. In all countries with a market economy, governmental organizations of appraisers are operating actively. The regulatory experience of valuation activity in the United States is rather indicative, the leading professional organizations are Appraisal Institute and the American Society of Appraisers (ASA). In 1987 they founded the Appraisal Foundation, which should serve the purpose of achieving uniformity and professionalism in the valuation and training. The operation of two independent bodies - Appraisal Standards Board and Appraisers Classification Board contributes to the latter. State regulation in the United States is organized both at the federal level and at the level of individual states. According to Financial Institution Reform, Recovery and Enforcement Act (FIRREA), adopted by Congress in 1989, the authority to regulate the valuation activities at the federal level, is given to the Appraisal Foundation. Simultaneously with the Foundation the structure of the United States Government includes the agency in charge of supervising the enforcement of appraisal laws - Appraisal Subcommittee. Appraisers Classification Board develops, interprets and amends the Uniform Standards of Professional Appraisers Practices - USPAP, required for use by practitioners (certified and licensed) appraisers throughout the United States. Appraisers Classification Board provides a minimum level of education experience and examination requirements for real estate appraisers.

Keywords: appraiser, self-regulatory organizations, market value, professional activity, legal regulation.

\section{Introduction}

Russia has recently experienced the process of transformation in methods and principles for regulating individual sectors of the economy, namely appraisal activities, auditing, operations of turnaround managers, etc. An alternative way of state regulation for these sectors of the economy is assigned at the legislative level, such as self-regulation, withdrawal of the state from direct regulation by a licensing mechanism, the concept of "private practice." However, a range of issues related to the legal regulation of these sectors of the economy, still does not have a unique solution

Table 1. Stages of Appraisal Activity Development in the Russian Federation.

\begin{tabular}{ll}
\hline Stages of Development & Description of Appraisal Activity Development \\
\hline \multirow{3}{*}{1 Stage } & From XV century to 1883 - establishment of appraisal activity and the appraisal mechanism \\
& for tax purposes \\
& From 1883 г. to 1917 - reappraisal of real estate. \\
& From 1917 no 1991 - appraisal activity ceased to exist because of transition to a centrally- \\
& planned economy. \\
& From 1991 to 2006 - establishment of appraisal activity in modern Russia together with \\
3 Stage & introduction of market relations, licensing of appraisal activity. \\
& From 2006 to the present day the current stage of appraisal activity development is underway, \\
& self-regulation of appraisal activity. \\
\hline
\end{tabular}

Self-regulation as a means of legal regulation in Russia is not new and is used in the regulation of lawyers and notaries, which can be attributed according to the accepted legal doctrine to the law enforcement authorities, which are 
assigned a number of public functions.

1. Legal regulation of appraisal activity;

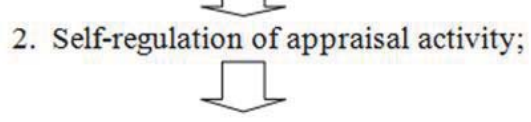

3. Contractual regulation.

Fig 1. Levels of Legal Regulation for Appraisal Activity

Features of these changes lie in the transfer of certain regulating, controlling and supervising functions in the stated sectors of the economy from the federal regulation body to non-governmental, self-regulatory organizations, and the formation of a mechanism to ensure the proper implementation of a number of regulating, controlling and supervising functions by non-government organization.

A self-regulatory system in the industrialized countries has long been present in many areas of public life. It has evolved and existed in parallel with state regulation of economic activity. This conversion of legislation affects all areas of law in Russia, but to a greater extent it has influenced the civil law.

It should be noted that the issue of professional valuation of property rights takes on new importance in the context of globalization. The need for international comparability of appraisal reports is increasing, not only in connection with the development of international investment funds, but also because of the increased mobility of private capital. One of the manifestations of these processes is the desire to develop and adopt common standards of appraisal activity, for example in the framework of a united Europe. However, the available results of this activity are estimated by most experts as skeptical, since the abandoning of prevailing unique requirements for the appraisal practice by each country seems a complexity.

At the current stage of appraisal institute development the following problems that hinder the establishment of a unified and efficient appraisal services market can be indicated:

- update legislation on appraisal activity due to changes in the regulatory system, Russia's entry into the international economic community;

- clarification of related legislation rules dealing with matters of the independent appraisal to ensure completeness and consistency of legislation on independent professional appraisal, enhancing the role of the appraiser in the economic turnover.

\section{Theory}

Considering the situation in the Russian Federation, in 2014 there were about 17,000 appraisers - members of the 11 self-regulatory organizations, with $80 \%$ of appraisers carrying on a professional appraisal on the basis of an employment contract with a legal entity.

In accordance with Art. 3 of the Federal Law "On Appraisal Activities in the Russian Federation» \# 135-FZ appraisal activity refers to the professional activities of valuation, while the subject of the appraisal activities under the Art. 4 of the Law are individuals who are members of one of the self-regulatory organizations of appraisers and insure their liability in accordance with the requirements of this Federal Law.

With respect to members of the self-regulatory organizations of appraisers, the concept of "professional activity" can be deployed as an independent and voluntary activity of individuals with vocational training (on the basis of higher education), carried out as a private practice or under an employment contract to provide services to assess the market (other) value of the property (assessment), and to obtain systematic income.

The main feature of the professional activity of the business is that the cost of the services provided by the citizen engaged in professional activities is determined by calculating the time spent on the provision of services rather than by the market (economic) categories of "demand" and "supply", with pricing and time-expenditures coordinated with the state body exercising supervision or control over the said activity (charged).

Unlike citizens engaged in business as a sole proprietor, a citizen engaged in professional activities in the form of private practice, may also engage in such activities as an employee under an employment agreement. That is, the regulation of professional activity has a shifted character.

Thus, the subject of regulation of professional activities (private activity) is the activity of providing professional 
services by the subject of the activity.

\section{Results}

At the moment one can distinguish the following conflicting issues in the regulation of the legal status of appraiser's professional activity:

Firstly, it is a question of regulating the work of appraisers under a labor contract. The contract for the valuation concludes a legal entity, and it is accordingly responsible for the contractual commitments. The valuation is performed by an appraiser - a physical person who is responsible to the customer and third parties to carry out this valuation and is obliged to insure such liability. In this case, an appraiser has contractual relationship only with the legal entity.

It turns out that the responsibility of an appraiser, even to the client comes from the fact of the valuation, i.e. is noncontractual, and the contract for valuation only makes sense if a legal entity could take on additional responsibility for the obligations of an appraiser.

Secondly, these special provisions precludes the possibility of using the provisions of the Civil Code on liability of legal persons for the actions of their employees to these cases. Based on the general Article 402 of the Civil Code actions of the debtor's employees in the performance of his obligations are considered the actions of the debtor. It is the debtor who is responsible for these actions, if they cause any failure to perform obligations.

With regard to the indemnity obligations the Art. 1068 of the Civil Code establishes the same approach. According to this a legal person compensates the damage caused by its employee in the performance of labor (employment, official) duties. In this case, employees are recognized as citizens performing work under an employment agreement (contract), as well as citizens performing work under civil law contracts, if they act or should have acted on the instructions of the relevant entity or citizen under its control for safety of work.

It also should be noted that the appraiser may be subject to civil liability and disciplinary liability for violation of legislation on appraisal activity in the preparation of the valuation report on the part of the self-regulatory organization of appraisers in accordance with Art. 24.4 of the Federal Law "On Appraisal Activities in the Russian Federation", as well as on the part of an employer, in the flesh to the termination of the employment contract by the employer in the cases under Art. 81 of the Labour Code of the Russian Federation.

At the same time grounds for dismissal may also include inconsistency with a position or job due to lack of qualifications, thereby under the current legislation the principle of appraiser independence can not be performed in full. An appraiser, working under an employment contract can become dependent on the employer, the interest of which is profit, not a professional activity. The said conflict of interests, in our opinion can be resolved, of one divides the powers of bringing an appraiser to disciplinary liability between self-regulatory organizations and an employer. In this case, an employer holds the grounds to bring an employee to a disciplinary responsibility, such as violation of labor regulations by an appraiser and issues of compliance to the legislation on appraisal activity should be hold by self-regulatory organizations.

In view of the foregoing, and the gaps in the regulation of this sector of the economy in our country, the experience of developed countries in this area seems interesting, particularly in the United States.

The main regulator of the valuation activities at the international level is the International Valuation Standards Committee (IVSC). The Committee was established by the Royal Institute of Chartered Surveyors (RICS), the American Society of Appraisers (ASA), professional organizations from Australia, New Zealand, Malaysia, India and Canada in 1981. Subsequently, the Committee also joined the majority of the TEGoVA (appraisers community of Europe). The main objectives of the International Valuation Standards Committee is to harmonize and consider the opinions of appraisers in the preparation of financial reporting standards, bringing the opinions of appraisers and advocacy of their interests in such organizations as the International Monetary Fund, Organization for Economic Cooperation and Development, the World Bank and the Basel Banking Committee.

At the moment in every European country, which is a member of the IVSC or TEGOVA, there are national regulatory regimes for valuation. In this case, the regulation of valuation in the United States is different, for example, from the regulation of valuation in the UK or Germany. In all countries with a market economy, governmental organizations of appraisers are operating actively.

The regulatory experience of valuation activity in the United States is rather indicative, the leading professional organizations are Appraisal Institute and the American Society of Appraisers (ASA). In 1987 they founded the Appraisal Foundation, which should serve the purpose of achieving uniformity and professionalism in the valuation and training. The operation of two independent bodies - Appraisal Standards Board and Appraisers Classification Board contributes to the latter. State regulation in the United States is organized both at the federal level and at the level of individual states. 
According to Financial Institution Reform, Recovery and Enforcement Act (FIRREA), adopted by Congress in 1989, the authority to regulate the valuation activities at the federal level, is given to the Appraisal Foundation. Simultaneously with the Foundation the structure of the United States Government includes the agency in charge of supervising the enforcement of appraisal laws - Appraisal Subcommittee. Appraisers Classification Board develops, interprets and amends the Uniform Standards of Professional Appraisers Practices - USPAP, required for use by practitioners (certified and licensed) appraisers throughout the United States. Appraisers Classification Board provides a minimum level of education experience and examination requirements for real estate appraisers.

At the state level valuation activities are regulated on the basis of local legislation by Regulatory Commission of valuation entrusted with the requirements for licensing and certification of real estate appraisers. Requirements for licensing and certification in some states are different, and to work in a particular state it is necessary to obtain the appropriate license, passing the qualifying examination.

It is noteworthy that in the United States the market valuation services were self-regulated until 1989. The transition to state licensing has been associated with the real estate crisis in the United States. Valuation of property is out of public authorities control, which resulted in massive unbiased appraisals for mortgage lending, placing municipal orders construction and in some other cases. It can be assumed that this situation is likely to develop in Russia during the financial crisis, given the generally accepted trends of overvaluation of real estate prices, especially in big cities.

Nevertheless, currently professional organizations of appraisers are very significant in the United States. They offer their members professional education at a high level and the possibility to affect the legislation for practicing professionals A professional organization can protect its members accused of any violations, if the result of the case may affect the profession as a whole.

It is very important that the association may impose disciplinary sanctions to those members whose behavior does not meet the highest professional standards. Of great importance is the opportunity to develop relationships with the people involved in the same business in the country and around the world

Uniform standards of professional appraisal practice (USPAP) are required for use in the United States and in other countries (Canada, Mexico, and others). They are developed and approved by the Appraisal Standards Board of Appraisal Foundation, non-profit educational organization founded in 1987 by the leading professional organizations of the USA.

\section{Conclusion}

Thus, summing up the research, we can conclude that the process of globalization affects the legal development of valuation activities in the Russian Federation: the update of the legislation in the field of valuation takes place due to changes in the regulatory system, the rules of related legislation dealing with matters of independent valuation are clarified to ensure the completeness and consistency of legislation on independent professional valuation.

\section{References}

Hin, P., 2012. Differences in organizing valuation activities in leading industrialized countries. http://smao.ru/ru/news/members/article_ 185.html (Accessed on April 3, 2012).

Fedotova M., 2012 Appraisals are liable for their reports with their own assets. http://bankir.ru/publikacii///marina-fedotova-za-svoiotcheti-ocenschiki-otvechaut-lichnim-imyschestvom-9739890/ (Accessed on May 3, 2011).

Kurbatov A., 2010. Responsibility of appraisers working under an employment contract, as the embodiment of a legal absurdity Corporate lawyer, 9: 12-15.

Chibisov, R., Maslennikova E., 2009. Comparison of valuation services market in Russia and abroad. Bulletin «RWAY», 168. http://www.rway-online.ru/Bulletinltem15_1397.aspx (Accessed on March, 2009).

Smith, H.E., 2004. Property and property rules. New York University Law Review, 79 (5): 1719-1798.

Fisher, J.D., D. Louziotis, 2013. Real Estate Appraisal and Valuation. Alternative Investments: Instruments, Performance, Benchmarks, and Strategies, pp. 185-211. DOI: 10.1002/9781118656501.ch10

Baronin, S.A., A.G. Yankov, S.A. Bizhanov, 2014. Assessing the cost of real estate lifecycle contracts in Russia's present-day economy and the characteristics of the European experience. Life Science Journal, 11 (Issue SPEC 8): 249-253.

Rijkswaterstaat, D.B.F.M., 2013. What is "life Cycle Cost"? www.rijkswaterstaat.nl/zakelijk/zakendoen_met_rws/werkwijzen/gww/ contracten_gww/dbfm (Accessed on December 13, 2013).

Definition and Meaning. Business Dictionary. 2013. www.businessdictionary.com/definition/lifecycle-cost.html (Accessed on December $6,2013)$.

Data from the National Council for evaluation. Self-regulatory organizations: the National Council for appraisal activities. http://www.appraiser.ru/default.aspx?Sectionld=530 (Accessed on June, 2014). 
Dodel, K., 2013. Private Firm Valuation and M\&A: Calculating Value and Estimating Discounts in the New Market Environment. Wiley; 1 edition. ISBN: 978-1-119-97878-7, pp: 204.

Kharisova F.I. and Rakhmanova I.I. Sampling in Tax Audit. World Applied Sciences Journal 31 (1): 138-142, 2014.

Orlova M.E., Khafizova A.R. The tax component of innovative activity assessment in the Russian Federation // Life Sciences Journal, 11 (11), pp. 328-333.

Bulnina I.S. International legal standards of the bar activity and its domestic security (using the example of the Russian Federation and France. Life Science Journal 2014; 11(6s): 469 - 472.

Selivanovskaya, J.I., Talan, M.V. Responsibility for legalization (laundering) of proceeds from crime in international statutory instruments and legislation of the russian federation. Life Science Journal Volume 11, Issue SPEC. ISSUE 8, 2014, Article number 31, Pages 150-154. 